\title{
The effect of oral clindamycin and rifampicin combination therapy in patients with hidradenitis suppurativa in Singapore
}

This article was published in the following Dove Press journal:

Clinical, Cosmetic and Investigational Dermatology

\author{
Harumi Ochi \\ Lixian Chris Tan \\ Hazel H Oon \\ Department of Dermatology, National \\ Skin Centre, Singapore
}

\begin{abstract}
Hidradenitis suppurativa (HS) is a chronic inflammatory disease of follicular occlusion characterized by abscesses, draining sinuses, and scarring. The efficacy and tolerability of combination treatment with oral clindamycin and rifampicin have previously been assessed in 4 studies including groups of Caucasian patients. Overall results are promising with reported improvement rates between $71.4 \%$ and $85.7 \%$. In this study, we propose that combination therapy is safe and efficacious in the treatment of HS, not only among Caucasians, but also in a group of Asian patients in Singapore.
\end{abstract}

Keywords: hidradenitis suppurativa, combination therapy, clindamycin, rifampicin

\section{Introduction}

Hidradenitis suppurativa (HS) is a chronic inflammatory disease of follicular occlusion. Although HS is not primarily an infectious disease, Staphylococcus aureus and Staphylococcus epidermidis are pathogens most frequently isolated as secondary colonizers. ${ }^{1}$ In this study, we propose that combination therapy with oral clindamycin and rifampicin is efficacious in the treatment of HS in a group of Asian patients in Singapore.

\section{Methodology}

This retrospective study assessed the efficacy of a 10-week course of oral clindamycin $300 \mathrm{mg}$ twice daily and oral rifampicin $300 \mathrm{mg}$ twice daily in the treatment of HS. Patients who received this combination therapy between 1 December 2012 and 31 July 2013 in a tertiary dermatological center in Singapore were included.

This study was approved as an audit by the Head of Acne Clinic of National Skin Centre (NSC), Singapore. As this was performed retrospectively, permission to access the medical records of the patients was granted by the Director of NSC. Patient consent was waived by the Head of Acne Clinic as data were de-identified and retrospective.

\section{Results}

Eleven patients ( 9 males) had a mean age of $24.5 \pm 8.8$ years. There were 6 Chinese (54.5\%), 4 Malays (36.3\%) and 1 Indian (9.1\%). Five were smokers (45.5\%), 6 were obese $(54.5 \%)$ and 1 had a family history of HS $(9.1 \%)$. The duration of HS prior to commencement of oral clindamycin and rifampicin ranged from 2 to 20 years. Eight patients $(72.7 \%)$ had previous treatments, including retinoids and antibiotics, with limited effect and persistent disease. At the end of 10 weeks of treatment, 7 of the
Correspondence: Harumi Ochi

Department of Dermatology, Nationa

Skin Centre, I Mandalay Road, 308205,

Singapore

Tel +6562534455

Fax +6562533225

Email ochi.harumi@mohh.com.sg 
11 patients $(63.6 \%)$ reported clinical improvement. Four patients had digital photography documenting response before and after treatment, and 2 blinded assessors evaluated the improvement using the HS Physician Global Assessment (PGA) score. Three patients achieved clear, minimal or mild scoring from all sites after completion of therapy, and 2 patients reported a 2-grade improvement relative to baseline from at least 1 site. There was only 1 patient (9.1\%) who reported side effects of nausea and vomiting and 1 patient (9.1\%) who defaulted follow-up (Table 1).

\section{Discussion}

The efficacy and tolerability of this combination treatment had previously been assessed in 4 studies. Overall results are promising with reported improvement rates between $71.4 \%$ and $85.7 \%{ }^{1-4}$ Statistically significant improvements in all quality-of-life dimensions of the Skindex-France questionnaire were also described in 1 study. $^{2}$

It is hypothesized that both the antibacterial and antiinflammatory properties of clindamycin and rifampicin are responsible for the beneficial effects in treating HS. Clindamycin is a lincosamide antibiotic that is active against Gram-positive cocci and anaerobic bacteria. It mediates inflammation by suppressing complement-derived chemotaxis of polymorphonuclear leukocytes. Rifampicin is a lipid-soluble, broad-spectrum antibiotic highly effective against $S$. aureus. Additionally, it modifies cell-mediated hypersensitivity by suppressing antigen-induced transformation of sensitized lymphocytes. Rapid emergence of bacterial resistance may result with rifampicin monotherapy. ${ }^{5}$ Hence, combination therapy is synergistic with reduced resistance rates and increased anti-inflammatory properties. Although

Table I Demographics of patients, previous treatments, response and side effects of combination therapy

\begin{tabular}{|c|c|c|c|c|c|c|c|c|c|}
\hline $\begin{array}{l}\text { Case } \\
\text { number }\end{array}$ & $\begin{array}{l}\text { Age } \\
\text { (years) }\end{array}$ & Gender & $\begin{array}{l}\text { Duration } \\
\text { of disease } \\
\text { (years) }\end{array}$ & $\begin{array}{l}\text { Affected } \\
\text { area(s) }\end{array}$ & Prior therapy & $\begin{array}{l}\text { Physician } \\
\text { clinical } \\
\text { assessment }\end{array}$ & $\begin{array}{l}\text { Pretreatment } \\
\text { PGA score }\end{array}$ & $\begin{array}{l}\text { Posttreatment } \\
\text { PGA score }\end{array}$ & $\begin{array}{l}\text { Reported } \\
\text { side } \\
\text { effects }\end{array}$ \\
\hline I & 18 & Male & 2 & $\begin{array}{l}\text { Axilla, } \\
\text { neck }\end{array}$ & $\begin{array}{l}\text { Doxycycline, topical } \\
\text { clindamycin }\end{array}$ & Improved & $\mathrm{Nil}$ & $\mathrm{Nil}$ & $\mathrm{Nil}$ \\
\hline 2 & 18 & Male & 4 & Perineal & $\begin{array}{l}\text { Doxycycline, } \\
\text { erythromycin, } \\
\text { isotretinoin, } \\
\text { minocycline }\end{array}$ & Improved & Nil & Nil & $\mathrm{Nil}$ \\
\hline 3 & 19 & Male & 9 & Perineal & $\begin{array}{l}\text { Bactrim, cephalexin, } \\
\text { doxycycline, } \\
\text { erythromycin, } \\
\text { isotretinoin, } \\
\text { minocycline }\end{array}$ & Improved & 2.75 & 1.50 & Nil \\
\hline 4 & 20 & Male & 6 & $\begin{array}{l}\text { Perineal, } \\
\text { axilla }\end{array}$ & $\begin{array}{l}\text { Augmentin, topical } \\
\text { clindamycin }\end{array}$ & Nonresponder & Nil & Nil & $\mathrm{Nil}$ \\
\hline 5 & 21 & Male & 13 & $\begin{array}{l}\text { Perineal, } \\
\text { axilla }\end{array}$ & $\begin{array}{l}\text { Doxycycline, topical } \\
\text { clindamycin }\end{array}$ & Improved & 2.67 & 1.00 & $\mathrm{Nil}$ \\
\hline 6 & 21 & Male & 3 & $\begin{array}{l}\text { Perineal, } \\
\text { axilla, neck }\end{array}$ & Nil & Improved & 1.75 & 2.00 & Nil \\
\hline 7 & 21 & Male & 3 & $\begin{array}{l}\text { Perineal, } \\
\text { back }\end{array}$ & Defaulted & Defaulted & Nil & Nil & Nil \\
\hline 8 & 22 & Male & 5 & Perineal & $\begin{array}{l}\text { Isotretinoin, } \\
\text { minocycline, topical } \\
\text { clindamycin }\end{array}$ & Improved & Nil & Nil & Nil \\
\hline 9 & 48 & Male & 20 & $\begin{array}{l}\text { Perineal, } \\
\text { axilla }\end{array}$ & $\begin{array}{l}\text { Augmentin, } \\
\text { acitretin. } \\
\text { ciprofloxacin, } \\
\text { clindamycin, } \\
\text { ceftriaxone, } \\
\text { isotretinoin, } \\
\text { infliximab }\end{array}$ & Nonresponder & 3.13 & 3.00 & Nil \\
\hline 10 & 27 & Female & 7 & $\begin{array}{l}\text { Perineal, } \\
\text { axilla }\end{array}$ & $\begin{array}{l}\text { Doxycycline, } \\
\text { isotretinoin }\end{array}$ & Nonresponder & Nil & Nil & $\begin{array}{l}\text { Nausea, } \\
\text { vomiting }\end{array}$ \\
\hline II & 35 & Female & 2 & $\begin{array}{l}\text { Perineal, } \\
\text { axilla }\end{array}$ & Nil & Improved & Nil & Nil & Nil \\
\hline
\end{tabular}

Abbreviation: PGA, Hidradenitis Suppurativa Physician Global Assessment. 
Table 2 Summarized data of the available studies on rifampicin-clindamycin in HS

\begin{tabular}{|c|c|c|c|c|c|}
\hline Reference & $\begin{array}{l}\text { Number of } \\
\text { patients }\end{array}$ & Treatment modalities & $\begin{array}{l}\text { Assessment of the } \\
\text { severity of HS }\end{array}$ & $\begin{array}{l}\text { Number of patients } \\
\text { with improvement }\end{array}$ & $\begin{array}{l}\text { Number of } \\
\text { patients with } \\
\text { side effects }\end{array}$ \\
\hline Bettoli et al' & 23 & $\begin{array}{l}\text { Rifampicin } 600 \mathrm{mg} \text { and } \\
\text { clindamycin } 600 \mathrm{mg} \text { for } 10 \text { weeks }\end{array}$ & $\begin{array}{l}\text { Sartorius } \\
\text { Number of exacerbations }\end{array}$ & $17 / 20(85 \%)$ & $3(13 \%)$ \\
\hline Gener et $\mathrm{al}^{2}$ & 116 & $\begin{array}{l}\text { Rifampicin } 600 \mathrm{mg} \text { and } \\
\text { clindamycin } 600 \mathrm{mg} \text { for } 10 \text { weeks }\end{array}$ & $\begin{array}{l}\text { Sartorius } \\
\text { Hurley } \\
\text { Skindex-France questionnaire } \\
\text { HS Patient Global } \\
\text { Assessment }\end{array}$ & $60 / 70(86 \%)$ & $10(14 \%)$ \\
\hline $\begin{array}{l}\text { Mendonça and } \\
\text { Griffiths }^{3}\end{array}$ & 14 & $\begin{array}{l}\text { Rifampicin } 600 \mathrm{mg} \text { and } \\
\text { clindamycin } 600 \mathrm{mg} \text { for } 10 \text { weeks }\end{array}$ & No specific score & $10 / 14(7 \mid \%)$ & $4(29 \%)$ \\
\hline $\begin{array}{l}\text { van der Zee } \\
\text { et al }{ }^{4}\end{array}$ & 34 & $\begin{array}{l}\text { Rifampicin and clindamycin } \\
\text { different dosages and duration }\end{array}$ & $\begin{array}{l}\text { Hurley } \\
\text { Investigator total assessment }\end{array}$ & $28 / 34(82 \%)$ & $13(38 \%)$ \\
\hline Present study & 11 & $\begin{array}{l}\text { Rifampicin } 600 \mathrm{mg} \text { and } \\
\text { clindamycin } 600 \mathrm{mg} 10 \text { weeks }\end{array}$ & $\begin{array}{l}\text { HS Physician Global } \\
\text { Assessment }\end{array}$ & $7 / 11(63.6 \%)$ & I (9.1\%) \\
\hline
\end{tabular}

Abbreviation: HS, hidradenitis suppurativa.

a longer duration of treatment appears warranted in chronic diseases like HS, no large differences in outcome between patients treated for 10 weeks or more and those treated for a shorter period have been reported. ${ }^{4}$

Other studies have similarly described good tolerability with low rates of side effects between $13.0 \%$ and $38.2 \%$ (Table 2). Gastrointestinal complaints were most commonly reported, but there were no cases of clindamycin-associated Clostridium difficile colitis. ${ }^{1-4}$

In a recent systematic review of HS treatment, only combination clindamycin-rifampicin regimen, infliximab, $\mathrm{Nd}$ :YAG laser and surgical excision were considered effective treatments. However, some of these modalities have limitations. Infliximab has resulted in adverse events including severe allergic reactions, multifocal motor neuropathy and drug-induced lupus reactions. Recurrence rates of up to $42.8 \%$ after surgical excision have also been described. ${ }^{6}$

\section{Conclusion}

Oral clindamycin and oral rifampicin combination therapy is safe and efficacious in the treatment of HS in groups of Caucasian and Asian patients in Singapore.

\section{Acknowledgment}

The authors thank Dr Heng Yee Kiat for assisting with the PGA scoring.

\section{Disclosure}

Dr Hazel H Oon has received research grants from Pfizer and Novartis and acted as a speaker for Novartis, Galderma, and AbbVie. The authors report no other conflicts of interest in this work.

\section{References}

1. Bettoli V, Zauli S, Borghi A, et al. Oral clindamycin and rifampicin in the treatment of hidradenitis suppurativa-acne inversa: a prospective study on 23 patients. J Eur Acad Dermatol Venereol. 2014;28(1):125-126.

2. Gener G, Canoui-Poitrine F, Revuz JE, et al. Combination therapy with clindamycin and rifampicin for hidradenitis suppurativa: a series of 116 consecutive patients. Dermatology. 2009;219(2):148-154.

3. Mendonça CO, Griffiths CE. Clindamycin and rifampicin combination therapy for hidradenitis suppurativa. Br J Dermatol. 2006;154(5): 977-978.

4. van der Zee HH, Boer J, Prens EP, Jemec GB. The effect of combined treatment with oral clindamycin and oral rifampicin in patients with hidradenitis suppurativa. Dermatology. 2009;219(2):143-147.

5. Van Vlem B, Vanholder R, De Paepe P, Vogelaers D, Ringoir S. Immunomodulating effects of antibiotics: literature review. Infection. 1996;24(4) 275-291.

6. Rambhatla PV, Lim HW, Hamzavi I. A systematic review of treatments for hidradenitis suppurativa. Arch Dermatol. 2012;148(4):439-446. and includes a very quick and fair peer-review system, which is all easy to use. Visit http://www.dovepress.com/testimonials.php to read real quotes from published authors 